\title{
E-Filing Behaviour among Academics in Perak State in Malaysia
}

\author{
M. Krishna Moorthy, Azni Suhaily Binti Samsuri, Suhaili Binti Mohd Hussin, \\ Maisarah Syazwani Binti Othman, Mahendra Kumar Chelliah \\ Department Commerce and Accountancy, Universiti Tunku Abdul Rahman, Perak Campus, Kampar, Malaysia \\ Email: krishnam@utar.edu.my, zazni@utar.edu.my, suhaili@utar.edu.my, maisarah@utar.edu.my, \\ mahendra@utar.edu.my
}

Received 13 February 2014; revised 13 March 2014; accepted 20 March 2014

Copyright (C) 2014 by authors and Scientific Research Publishing Inc.

This work is licensed under the Creative Commons Attribution International License (CC BY). http://creativecommons.org/licenses/by/4.0/

(c) (7) Open Access

\begin{abstract}
Perak State government in Malaysia has been promoting an Internet tax filing called electronic filing as part of its e-government initiative. Starting in year 2006, Malaysia Inland Revenue Board (IRBM) has launched the e-filing method for individual taxpayers and from that point of time, Malaysia's citizens are provided with the option to choose their tax filing method either in the way of manual tax-filing method or e-filing method. This study focuses on the Perak State academics' intention and behavior to adopt e-filing tax system. The target population for this study is academic staff in Perak State in Malaysia. 116 usable questionnaires were collected from three public institutions and two private institutions of higher learning in Perak State in Malaysia and the data analyzed through the SPSS. The findings show that perceived use of use, perceived usefulness, perceived security, and perceived credibility do influence the Perak State academic's e-filing adoption intention. However, perceived service and information quality has not influenced their e-filing adoption intention. This study provides several important implications for building and promoting effective e-filing system by the IRBM.
\end{abstract}

\section{Keywords}

E-Filing, Tax Filing, E-Filing Behavior, E-Filing Adoption, Malaysia

\section{Introduction}

\subsection{Research Background}

Multimedia Super Corridor Malaysia (MSC Malaysia) has been promoted by the Perak State Government for the initiative to leapfrog the nation into a knowledge-based economy level [1]. Among seven flagship applica- 
tions, Perak State government has been promoting an Internet tax filing called electronic filing as part of its e-government initiative [2]. Starting in year 2006, Malaysia Inland Revenue Board (IRBM) has launched the e-filing method for individual taxpayers and from that point of time, Malaysia's citizens are provided with the option to choose their tax filing method either in the way of manual tax-filing method or e-filing method [2] [3]. E-filing tax system is an application on filing information of tax payment and tax return forms (ITRF) electronically by obtaining a valid digital certificate from the Inland Revenue Board Malaysia (IRBM). This valid digital certificate is to help taxpayers to complete their tax filing online. This shows an obvious contrast between the traditional manual tax filing method and e-filing tax method where the transaction process can be done in a paperless environment and rather without physically paying a visit to the tax department.

\subsection{Problem Statement}

Despite several benefits and advantages provided to taxpayers in terms of information searching, speedy filing, minimizing processing errors, fast and direct deposit refunds, eliminating delays or uncertainties of tax filing and return by postal mail [4]-[6], statistics from IRBM indicates that taxpayers who adopt e-filing tax system represent only 67 percent of total taxpayer's population in year 2011. There is a slight increase of 2 percent compared to the year 2010 where the e-filing users represent 65 percent of total academics' population. This increase is not showing a significant value, but this increase shows that the awareness and responds are shown by the taxpayers. According to WASEDA e-Government development ranking survey from Japan in year 2012, Malaysia remained in the $23^{\text {rd }}$ position in the rankings among the 55 countries as in the years 2010 and 2011, though many efforts have been made by the government to promote e-government services. Perak State tax authorities seem to face some major challenges towards the implementation of the e-filing tax system, as the success and acceptance of e-government services depends on citizens' willingness to utilize the government service provided [7]. This study focuses on the Perak State academics' intention to adopt e-filing tax system.

\subsection{Research Objectives}

1) To examine the relationship between perceived ease of use (PEOU) and Perak State academics' e-filing adoption intention.

2) To examine the relationship between perceived usefulness (PU) and Perak State academics' e-filing adoption intention.

3) To examine the relationship between perceived security and Perak State academics' e-filing adoption intention.

4) To examine the relationship between perceived credibility and Perak State academics' e-filing adoption intention.

5) To examine the relationship between perceived service and information quality and Perak State academics' e-filing adoption intention.

6) To examine the relationship between Perak State academics' e-filing adoption intention and e-filing behavior.

\subsection{Research Questions}

1) What is the relationship between perceived ease of use (PEOU) and Perak State academics' e-filing adoption intention?

2) What is the relationship between perceived usefulness (PU) and Perak State academics' e-filing adoption intention?

3) What is the relationship between perceived security and Perak State academics' e-filing adoption intention?

4) What is the relationship between perceived credibility and Perak State academics' e-filing adoption intention?

5) What is the relationship between perceived service and information quality and Perak State academics' e-filing adoption intention?

6) What is the relationship between Perak State academics' e-filing adoption intention and e-filing behaviour?

\section{Theoretical Foundation}

\subsection{Technology Acceptance Model (TAM)}

TAM is an adaption of Theory of Reasoned Action (TRA) proposed by Ajzen in 1980. TAM was developed by 
Fred Davis in 1986. This model suggests that perceived usefulness (PU) and perceived ease of use (PEOU) determine an individual's intention to use a new technology or system. PU is defined as the degree that a person believes to an extent that adoption of a particular system will enhance their job performance [8]. PEOU refers to degree of easiness that an individual learns to operate the new technology or information system. In addition, TAM is being used and accepted in most of the past studies to explain the relationship between the usage perception and information technology.

TAM is being verified as a useful theoretical model to understand and explain the user's behaviour to implement an information system (IS). Besides, many empirical researches have been conducted in order to test the TAM. The results have proved the quality of TAM and yielded statistically reliable results [9]. In addition, citizen's intention for using the e-Government system has been strongly influenced by TAM [10].

TAM is being applied in most researches of information technology. TAM has been used to explore taxpayer's acceptance towards the Internet tax-filing system [11]. Besides, TAM is combined with social influences and flow experience to forcast the on-line games towards users' acceptance [12]. In addition, combination of TAM and TPB was applied to investigate the customer's intention in using online banking [13]. Follow up studies discussed the explanation and prediction of the users' acceptance towards corporate information technology in the context of TAM [10]. TAM is incorporated in most of researches to understand or explore factors towards acceptance of various types of information technology.

\subsection{Theory of Planned Behaviour (TPB)}

TPB is a theory about the link between attitudes and behaviour. It was proposed by Ajzen in 1991 [14]. The TPB is an extension of Theory of Reasoned Action (TRA) made necessary by the original model's limitations in dealing with behaviours over which people have incomplete volitional control [14]. The theory states that the attitude, subjective norm and perceived behavioural control, together shape an individual's behavioural intentions. Attitude refers to positive and negative evaluation for self performance of a particular behaviour. Subjective norm refers to the perception about a particular behaviour of a person influenced by the judgement from significant surrounding person/s. Perceived behavioural control refers to an individual's perceived easy or difficult to perform particular behaviour [15]. Intentions are major determinants of actual performance in the TPB and their role in predicting actual performance has been empirically validated [16].

This research intends to adopt both TAM and TPB theories as its theoretical foundation because of the application of IT, intention, and behaviour in the Perak State academics' e-filing.

\subsection{E-Filing Adoption Intention and Behaviour}

E-filing implementation was introduced by the government agency called Lembaga Hasil Dalam Negeri (LHDN) and it allows taxpayers to submit their income tax details online and is considered as an alternative to the usual manual paper submission [17]. Thus, the implementation of this service can help the government to achieve their objectives by becoming more effective in operational and processing tasks and can provide greater convenience for taxpayers.

The words "intention" comes from Latin word "intendere" meaning "to stretch toward or to aim at" [18]. Thus, intention can be better to be described as a course of action that one proposes to follow. Therefore, in this study, intention is the process by which academics are able to follow all the action or process to produce their meaningful experience of the e-filing tool in filing their tax returns.

People's acceptance of e-filing is highly related to their behaviour on the one hand, ease and usefulness of e-filing system as well as security, credibility and quality support on the other. In 2010, mail surveys were distributed to personal taxpayers by the Inland Revenue Board of Malaysia and the result was utilised to determine the factors significantly affecting people's actual usage behaviour of the e-filing system. The results suggest that few factors are significant in explaining the actual usage behaviour of the e-filing system among the personal taxpayers. Thus, the following hypothesis is proposed:

H1: There is a relationship between Perak State academics' e-filing adoption intention and e-filing behaviour.

\subsection{Perceived Ease of Use}

An increase and improvement of e-filing system offers the essential base for user's perceptions of ease of use. 
E-filing system offers many benefits to tax payers but all depend on the willingness to accept and use the available electronic services. Thus, website for Inland Revenue Board (IRB) is an important mechanism in the assessment of the ease of use for the user to file tax forms online. In the last couple of years, the developments on the web site have been improved and appreciated by users. Perceived ease of use is an individual's assessment of the extent to which interaction with a specific information system or technology is free of mental effort [8]. The perceived ease of use for a system is defined as the degree to which an individual believes that using a particular technology will be free of effort [19].

The results of many past researchers have provided evidence of the significant effect of perceived of usefulness and perceived ease of use on behavioural intention [20]-[27]. Perceived ease of use also found to have a significant impact on attitude, thus affects behaviour intentions [11]. Based on the discussion above, the hypothesis will be tested as below:

H2: There is a relationship between perceived ease of use (PEU) and Perak State academics' e-filing adoption intention.

\subsection{Perceived Usefulness}

TAM posits that perceived usefulness (PU) and perceived ease of use (PEU) are significant factors affecting acceptance of an information system and influence behavioural intention and attitude towards actual usage by the computer users. Perceived usefulness refers to the extent to which a person believes that using a particular system will enhance his or her performance [8]. According to Mathwick et al. [28], perceived usefulness is the extent to which a person deems a particular system to boost his or her job performance. The perceived usefulness will reflect the belief that using the technology will enhance performance [17]. The importance of perceived usefulness has been widely recognized in various fields. Past studies showed that perceived usefulness has a direct influence on behavioural intention to adapt online shopping, web-based training, electronic banking, e-commerce, and e-government services like e-filing [29]-[32].

Many studies have found that tax payers' perception towards e-filing system is influenced by perceived usefulness. Another example is Ambali [17] who examined the user's perceptual retention on the new electronic income-tax-filing system in Malaysia and implied that PU is influential and potential contributing factor to users' retention.Thus, the following hypothesis is proposed:

H3: There is a relationship between perceived usefulness (PU) and Perak State academics' e-filing adoption intention.

\subsection{Perceived Security}

Internet has provided greater convenience for tax payers to file taxes and make use of the online services. However, some believe (taxpayers) that they are able to file their income taxes manually rather than using the internet medium as advantage. The major issue here is whether the security of the system and information can give perception of confidence among tax payers or not. According to Belanger et al. [33], the biggest challenges presented by this issue related to privacy and security. Ambali [17] also highlighted security is a major factor but people are not often worry about security in physical way. But, when it is comes to e-filing, people are concerned more about their security information required in the system. Therefore, it can be concluded that people may perceive that the facilities in electronic tools are not adequately secured.

According to Valacich and Schneider [34], system security is a precaution to keep the system from unauthorized access and use while perceived information security is defined as the subjective probability with which consumers believe that their personal information will not be viewed, stored or manipulated during transit or storage by inappropriate parties, in a manner consistent with their confident expectations [35]. Iqbal and Bagga [27] also highlighted that there is personal sensitivity on individual data when a taxpayer files the information. Hence, effective measures must be taken to protect sensitive personal information such as income and medical history. Previous study also found that there was a strong relationship between the effectiveness of e-government security in term of availability, integrity, confidentiality and accountability [36] [37].

In Malaysia, action also was taken from Inland Revenue Board to educate tax payers.

"While the Internet has provided greater convenience for tax payers to file taxes and make payments through our online services, every tax payer is responsible for their online safety by ensuring that they practice safe online habits when using these services." Dato' Dr. MohdShukor bin Haji Mahfar, CEO of IRB Malaysia. In addi- 
tion, he also urged tax payers to be careful and stay safe when filing taxes and making payments online. Inland Revenue Board (Malaysia) is also cooperating with Symantec which worked together to educate tax payers to follow a set of best practices to ensure that tax payers have positive e-filing and payment experiences.

Moreover, whether the tax software are verified based on the policy is also still not clear and people keep asking whether it is safe to e-file their income taxes or not [38]. However, the chances are slim-to-none if all tax software should guarantee that it uses the most secured technology. It is supported by Udo [39] who explained that every site which is sensitive to privacy concern should have privacy policies clearly displayed. Thus, the following hypothesis is proposed:

H4: There is a relationship between perceived security (PS) and Perak State academics' e-filing adoption intention.

\subsection{Perceived Credibility}

Perceived credibility is the quality of the e-filing system being trusted by the users in terms of ability to protect the user's personal information and security [39]. Perceived credibility in tax e-filing will affect the intention to adopt the e-filing applications and increase behavioural uncertainty since it involves the exchange of personal and private information. Based on Ambali [17], majority of the taxpayer population reluctant to use this alternative medium of filing their tax returns might be because the security violations in internet-based systems have received bad reputation in the popular sections of press and mind of the people all over the world.

According to Wang [26], perceived credibility refers to two dimensions which are security and privacy affecting users' intention to adopt the online transaction systems. Lai et al. [40] found that some users would only use the e-filing system if the Inland Revenue Board (IRB) could assure that the e-filing system is safe and secured audits usability and reliability are fully tested and well documented. If users are able to feel that the e-filing system is secured and trustworthy, the users will have no doubt to put trust and use it. Previous studies found that perceived usefulness have significant influence on behavioural intention in the context of electronic tax filing (e.g., Ilias, Razak, \& Yasoa [41], Sharma \& Yadav [2] and Wang [26]. Thus, the following hypothesis is proposed:

H5: There is a relationship between perceived credibility (PC) and Perak State academics' e-filing adoption intention.

\subsection{Perceived Service and Information Quality}

Ilhaamie [42] highlighted that service quality is an important dimension of organizational performance in the public sector as the main output of public organizations. Nowadays, the process of transformation from government to e-Government services makes a new generation in public services [43]. E-filing for income taxes is one of e-Government services that can replace the government's traditional services for better quantity, quality, and satisfactory results. In addition, the quality of the services is another incentive from government to promote the use of e-Government services. It is highlighted that the individual can spend less time and do not have to wait in a queue in order to receive the services.

Hence, the major issue of service quality in this matter expected is quite low. Therefore, Abdullah [44] explained that it is a matter concerned to the public since they are the taxpayers and they expect good services are provided to them. Aliah and Tarmize [45] by adopting SERVQUAL in their study had measured service quality provided by an income tax payment department in Malaysia. They concluded that there were existence of significant gaps between the expectations of the income tax payers and the services they received such as reliability, responsiveness and empathy.

From the perspective of tax payers' behaviour relating to service quality, the problems occurred in term of the system or website practices. Not all tax payers are computer literate and it is believed that some of them are doubt in using this kind of services. However, the comfort zone of tolerance exists as the income tax payers are willing to compromise with this matter [42]. The most important factor in information quality is the accuracy of information provided by user when they enter the data in the e-filling system. Another aspect would be either information acquired by the system is relevant for users. Based on Chang et al. [11], information quality has been defined by the degree to which users are provided with quality information regarding their needs. Information quality also represents the users' perception of the output quality generated by an information system and includes such issues as the relevance, timeliness and accuracy [46]. 
If a system could provide users with relevant information on time, accurate, understandable and help in a better decision making, the user will choose to use it. This is because, users could perceive the system as greater job relevance, high output quality and greater result demonstrability [47]. Thus, the following hypothesis is proposed:

H6: There is a relationship between perceived service and information quality (PSIQ) and Perak State academics' e-filing adoption intention.

The above discussion leads to the theoretical framework of this research and shown in Figure 1.

\section{Methodology}

The target population for this study is academic staff from three public institutions and two private institutions of higher learning in Perak Sate in Malaysia. This study took approximately 3 months whereby 200 questionnaires were distributed to the academic staff. The overall response rate was 58\% which means 116 questionnaires were returned and completed by the respondents. The variables for this study were measured using a list of 35 items adapted from past study, Sharma \& Yadav [2]. All the 7 variables were measured using a 5-point Likert-type scale $(1=$ strongly disagree to $5=$ strongly agree). SPSS 17 was used to analyse the data.

The multivariate statistical technique, Multiple Regression Analysis has been used to examine the linear correlations between the five independent variables and mediating variable. Simple Regression Analysis has been used to examine the linear correlation between the mediating and dependent variables.

\section{Results, Analysis and Findings}

Several analysis including descriptive statistics, correlation analysis, multiple linear regression analysis and simple linear regression analysis are performed and discussed in the following paragraphs.

\subsection{Respondents' Profile}

Table 1 shows the profile of the respondents.

It could be seen from Table 1 that 92.2 percent of the respondents are online users while manual users consist of 7.8 percent. The sample also indicates that female respondents represented a higher percentage of the total samples (67.2\%) when compared to the male respondents (32.8\%). Most of the respondents fall into the age group between 31 to 40 years old (44\%) followed by those between 41 to 50 years old (28.4\%). Single respondents indicate 34.5 percent while married respondents consist of 65.6 percent. Majority of the respondents possess Masters (57.8\%) while 25.9 percent had completed their PHD. Most of the respondents fall into income group within RM 3501 to RM 4500 (34.5\%) followed by the income level between RM 5501 or above (32.8\%). Majority of the respondents used broadband to connect to the internet (85.30\%) while 11.20 percent did not have the internet connection at home. The respondents used broadband to connect to the internet at the office (48.40\%) followed by 41.40 percent who used LAN. Respondents used the internet for 8 hours or above (50\%) while 26.7 percent of the respondents used internet between 5 to 7 hours.

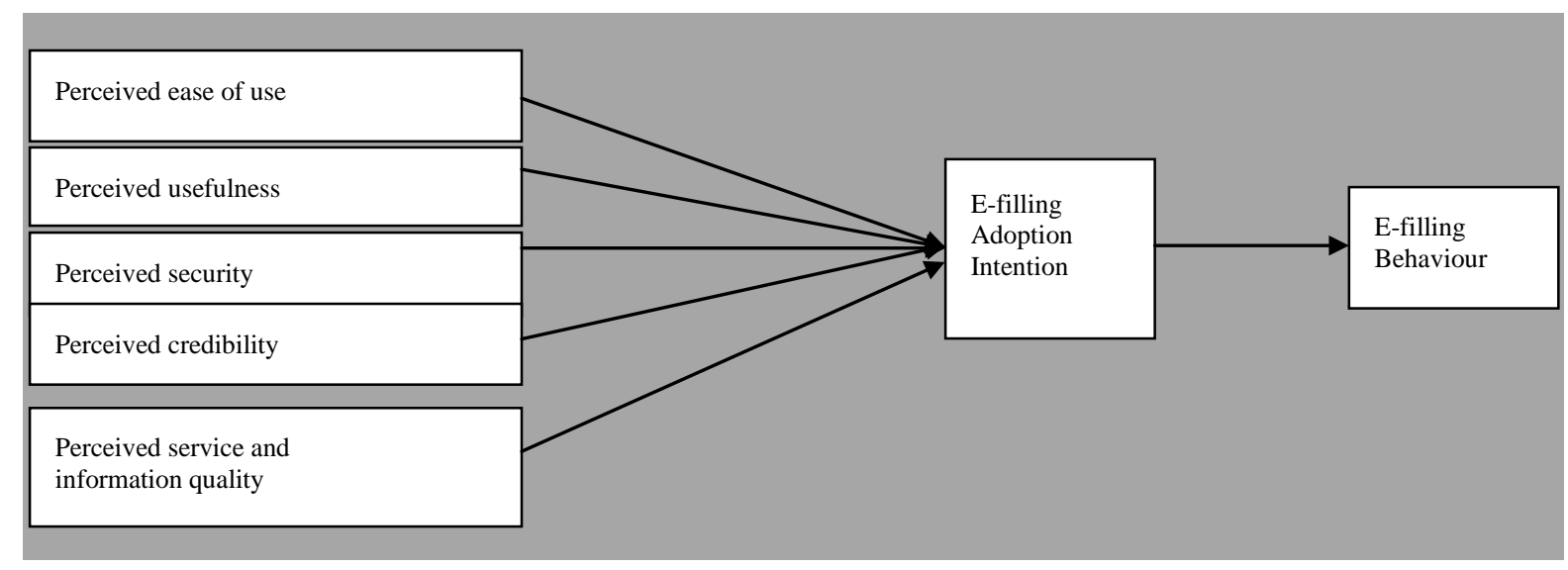

Figure 1. Research framework. 
Table 1. Respondents' profile $(\mathrm{N}=116)$.

\begin{tabular}{|c|c|c|}
\hline Items & Frequency & Percentage \\
\hline \multicolumn{3}{|l|}{ Tax filing method } \\
\hline Manual & 9 & 7.8 \\
\hline Online & 107 & 92.2 \\
\hline \multicolumn{3}{|l|}{ Gender } \\
\hline Male & 38 & 32.8 \\
\hline Female & 78 & 67.2 \\
\hline \multicolumn{3}{|l|}{ Age } \\
\hline 21 - 30 years old & 20 & 17.2 \\
\hline 31 - 40 years old & 51 & 44.0 \\
\hline 41 - 50 years old & 33 & 28.4 \\
\hline 51 years and above & 12 & 10.4 \\
\hline \multicolumn{3}{|l|}{ Marital status } \\
\hline Single & 40 & 34.5 \\
\hline Married & 76 & 65.5 \\
\hline \multicolumn{3}{|l|}{ Education } \\
\hline Bachelor degree & 15 & 12.9 \\
\hline Master degree & 67 & 57.8 \\
\hline $\mathrm{PhD}$ & 30 & 25.9 \\
\hline Specialist & 4 & 3.4 \\
\hline \multicolumn{3}{|l|}{ Monthly income level } \\
\hline RM 2500 - 3500 & 12 & 10.3 \\
\hline RM 3501 - 4500 & 40 & 34.5 \\
\hline RM 4501 - 5500 & 26 & 22.4 \\
\hline RM 5501 and above & 38 & 32.8 \\
\hline \multicolumn{3}{|c|}{ Computer and network facilities at home } \\
\hline No internet & 13 & 11.2 \\
\hline Dial-up & 4 & 3.4 \\
\hline Broadband & 99 & 85.3 \\
\hline \multicolumn{3}{|c|}{ Computer and network facilities at work } \\
\hline No internet & 5 & 4.3 \\
\hline Dial-up & 7 & 6.0 \\
\hline LAN & 48 & 41.4 \\
\hline Broadband & 56 & 48.3 \\
\hline \multicolumn{3}{|c|}{ Hours of computer use in a week } \\
\hline 1 hour or less & 1 & 0.9 \\
\hline 2 - 4 hours & 26 & 22.4 \\
\hline $5-7$ hours & 31 & 26.7 \\
\hline 8 hours and above & 58 & 50.0 \\
\hline
\end{tabular}




\subsection{Measurement of Central Tendencies}

Table 2 shows the central tendencies measurement and Cronbach Alpha.

The highest mean is for the question "feel secure if the officer received and accepted e-filing return" (Mean = 4.13 , SD = 0.704) followed by "e-filing speed up the tax filing process" (Mean = 4.07, SD = 0.754). The mean for all variables are above 3.41 while standard deviations are all less than $3.0(<3.0)$. The results are all good and appropriate for the study.

According to the Table 2, the Cronbach's Alpha value for PEU is 0.765 , PU is 0.881 , PS is 0.788 , PC is 0.834 , PSIQ is 0.856 , EAI is 0.861 , and EB is 0.791 . Thus, the reliability coefficients of all IVs and DVs are above the accepted criteria of 0.70 .

\subsection{Normality}

The normality test showed that all items of the variables resulted in less than 3 skewness and less than 10 kurtosis which met the most stringent demand of multivariate normality of the variance [38].

\subsection{Correlation}

All correlations are significant. Table 3 shows that the highest correlation is between e-filing behaviour (EB) and e-filing adoption intention (EAI) $(\mathrm{p}=0.860)$.

\subsection{Inferential Analysis}

\section{Multiple Linear Regression}

The R Square shows the extent or percentage the independent variables can explain the variation in the mediating variable. $\mathrm{R}$ square shown in Table 4 at 0.728 indicates that $72.80 \%$ of the changes in mediating variable (e-filing adoption intention) can be explained by the independent variables (perceived ease of use, perceived usefulness, perceived security, perceived credibility and perceives service and information quality). However, the remaining $27.20 \%$ (100\% - 72.80\%) of variation could be explained by other variables which are not considered in this study.

As shown in the Table 5, F-value statistics is derived at 59.02 which are fairly large. Based on the analysis, the significant p-value is arrived as 0.000, which is less than 0.05 (p-value < 0.05). Both F-value statistics and p value provide a good model fit for this study.

While Table 6 shows that perceived service and information quality alone does not influence the E filing adoption intention by not meeting the requirement of $\mathrm{p}$-value $<0.05$. Other independent variables perceived ease of use, perceived usefulness, perceived security and perceived credibility influence the E-filing intention with p-value below 0.05 .

Table 7 shows the result of simple linear regression. The R square shows the extent or percentage the mediating variable can explain the variations in the dependent variable. $\mathrm{R}$ square at 0.739 indicates that $73.90 \%$ of the changes in dependent variable can be explained by the mediating variable E-filing adoption intention. However, the remaining $26.10 \%$ of variation could be explained by other variables which are not considered in this study.

Table 2. Central tendencies measurement of constructs.

$\begin{array}{ccc}\text { Variable } & \text { Mean } & \text { Standard deviation } \\ \text { Perceived ease of use } & 3.8787 & 0.7234 \\ \text { Perceived usefulness } & 4.0221 & 0.7575 \\ \text { Perceived security } & 4.0591 & 0.6921 \\ \text { Perceived credibility } & 3.4123 & 0.7336 \\ \text { Perceived service and information quality } & 3.9615 & 0.689 \\ \text { E-filing adoption intention } & 3.6725 & 0.834 \\ \text { E-filing behaviour } & 3.8562 & 0.7132 \\ 0.856\end{array}$


Table 3. Correlation analysis.

\begin{tabular}{|c|c|c|c|c|c|c|c|c|}
\hline & & EB & EAI & PEU & PU & PS & PC & PSQ \\
\hline \multirow{3}{*}{ EB } & Pearson correlation & 1.000 & $0.860^{* * *}$ & $0.686^{* *}$ & $0.671^{* *}$ & $0.742^{* *}$ & $0.731^{* *}$ & $0.809^{* *}$ \\
\hline & Sig. (2-tailed) & & 0.000 & 0.000 & 0.000 & 0.000 & 0.000 & 0.000 \\
\hline & $\mathrm{N}$ & & 116 & 116 & 116 & 116 & 116 & 116 \\
\hline \multirow{3}{*}{ EAI } & Pearson correlation & & 1.000 & $0.670^{* *}$ & $0.626^{* *}$ & $0.766^{* *}$ & $0.707^{* * *}$ & $0.829^{* *}$ \\
\hline & Sig. (2-tailed) & & & 0.000 & 0.000 & 0.000 & 0.000 & 0.000 \\
\hline & $\mathrm{N}$ & & & 116 & 116 & 116 & 116 & 116 \\
\hline \multirow{3}{*}{ PEU } & Pearson correlation & & & 1.000 & $0.854^{* *}$ & $0.624^{* *}$ & $0.634^{* * *}$ & $0.695^{* *}$ \\
\hline & Sig. (2-tailed) & & & & 0.000 & 0.000 & 0.000 & 0.000 \\
\hline & $\mathrm{N}$ & & & & 116 & 116 & 116 & 116 \\
\hline \multirow{3}{*}{$\mathrm{PU}$} & Pearson correlation & & & & 1.000 & $0.618^{* *}$ & $0.611^{* *}$ & $0.682^{* *}$ \\
\hline & Sig. (2-tailed) & & & & & 0.000 & 0.000 & 0.000 \\
\hline & $\mathrm{N}$ & & & & & 116 & 116 & 116 \\
\hline \multirow{3}{*}{ PS } & Pearson correlation & & & & & 1.000 & $0.738^{* * *}$ & $0.815^{* *}$ \\
\hline & Sig. (2-tailed) & & & & & & 0.000 & 0.000 \\
\hline & $\mathrm{N}$ & & & & & & 116 & 116 \\
\hline \multirow{3}{*}{ PC } & Pearson correlation & & & & & & 1.000 & $0.750^{* *}$ \\
\hline & Sig. (2-tailed) & & & & & & & 0.000 \\
\hline & $\mathrm{N}$ & & & & & & & 116 \\
\hline \multirow{3}{*}{ PSQ } & Pearson correlation & & & & & & & 1.000 \\
\hline & Sig. (2-tailed) & & & & & & & \\
\hline & $\mathrm{N}$ & & & & & & & \\
\hline
\end{tabular}

${ }^{* * *}$ Correlation is significant at the 0.01 level (2-tailed).

Table 4. Multiple liner regression.

\begin{tabular}{|c|c|c|c|c|c|c|c|c|c|}
\hline \multirow{2}{*}{ Model } & \multirow{2}{*}{$\mathrm{R}$} & \multirow{2}{*}{ R square } & \multirow{2}{*}{ Adjusted R square } & \multirow{2}{*}{ Std. error of the estimate } & \multicolumn{5}{|c|}{ Change statistics } \\
\hline & & & & & R square change & F change & df1 & df2 & Sig. F change \\
\hline 1 & $0.853^{\mathrm{a}}$ & 0.728 & 0.716 & 0.31091 & 0.728 & 59.020 & 5 & 110 & 0.000 \\
\hline
\end{tabular}

a Predictors: (Constant), PSQ, PU, PC, PS, PEU.

Table 5. Multiple liner regression-ANOVA.

\begin{tabular}{|c|c|c|c|c|c|c|}
\hline & Model & Sum of squares & df & Mean square & $\mathrm{F}$ & Sig. \\
\hline \multirow{3}{*}{1} & Regression & 28.526 & 5 & 5.705 & 59.020 & $0.000^{\mathrm{a}}$ \\
\hline & Residual & 10.633 & 110 & 0.097 & & \\
\hline & Total & 39.159 & 115 & & & \\
\hline
\end{tabular}

${ }^{\mathrm{a}}$ Predictors: (Constant), PSQ, PU, PC, PS, PEU; ${ }^{\mathrm{b}}$ Dependent Variable: EAI. 
Table 6. Multi liner regression-coefficients.

\begin{tabular}{|c|c|c|c|c|c|c|}
\hline & \multirow{2}{*}{ Model } & \multicolumn{2}{|c|}{ Unstandardized coefficients } & \multirow{2}{*}{$\begin{array}{c}\text { Standardized coefficients } \\
\text { Beta }\end{array}$} & \multirow[t]{2}{*}{$\mathrm{t}$} & \multirow[t]{2}{*}{ Sig. } \\
\hline & & B & Std. error & & & \\
\hline \multirow{6}{*}{1} & (Constant) & 0.411 & 0.119 & & 3.441 & 0.001 \\
\hline & PEU & 0.331 & 0.045 & 0.320 & 7.275 & 0.000 \\
\hline & PU & 0.325 & 0.045 & 0.346 & 7.163 & 0.000 \\
\hline & PS & 0.105 & 0.039 & 0.119 & 2.690 & 0.007 \\
\hline & PC & 0.173 & 0.042 & 0.166 & 4.097 & 0.000 \\
\hline & PSQ & 0.220 & 0.103 & 0.299 & 5.052 & 0.070 \\
\hline
\end{tabular}

${ }^{\mathrm{a}}$ Dependent Variable: EAI.

Table 7. Simple liner regression.

\begin{tabular}{|c|c|c|c|c|c|c|c|c|c|}
\hline \multirow{2}{*}{ Model } & \multirow{2}{*}{$\mathrm{R}$} & \multirow{2}{*}{ R square } & \multirow{2}{*}{ Adjusted R square } & \multirow{2}{*}{ Std. error of the estimate } & \multicolumn{5}{|c|}{ Change statistics } \\
\hline & & & & & R square change & F change & df1 & df2 & Sig. F change \\
\hline 1 & $0.860^{\mathrm{a}}$ & 0.739 & 0.737 & 0.30020 & 0.739 & 322.771 & 1 & 114 & 0.000 \\
\hline
\end{tabular}

${ }^{\mathrm{a}}$ Predictors: (Constant), EAI.

As shown in the Table 8, F-value statistics is derived at 322.771 which are very high. Based on the analysis, the significant p-value is 0.000 , which is less than 0.05 (p-value $<0.05$ ). Both F-value statistics and p value provide a good model fit between the mediating and dependent variables in this study.

Table 9 shows that the e-filing adoption intention influences the e-filing behaviour by meeting the requirement of p-value $<0.05$. In addition, the result also shows that e-filing adoption intention has positive relationship with the e-filing behaviour.

The summary of the hypotheses and results of the analysis are given in Table 10.

\section{Discussion on Findings}

From the findings it could be seen that perceived ease of use and perceived usefulness influence the e-filing adoption intention more than any other factors. It could be also seen that perceived security and perceived credibility also influence the e-filing adoption intention. These results are on line with the past studies as reviewed under the literature review part. However, this study concludes that perceived service and information quality do not influence the e-filing behaviour of the academics in Perak State. Perhaps the academics in Perak State have fully satisfied with the present service and information quality of the IRBM and they never considered these as factors to influence their e-filing adoption intention.

\section{Theoretical and Managerial Implications}

This study indicates some picture of the taxpayer's behaviour. This is important to understand the new system being implemented by LHDN and being accepted by the taxpayers. From the study, the TAM model and TPB theory have been validated through the results with a good model fit and by accepting five hypotheses over 6 hypotheses. In terms of managerial perspective it is important to LHDN to understand the timing of implementation and to understand the need of back up to cater the misunderstood perception of certain taxpayers. The main aim of LHDN is to collect as much as possible in a user friendly manner from the tax payers. It is not an easy task to have a healthy connection between LHDN and the taxpayers, but from this study it could help the management to understand the characters of the different level taxpayer's perceived reaction and behaviour. From this research it can be concluded that the management should upgrade their system in order to minimize the concern by the tax payers in adopting this e-filling. 
Table 8. Simple liner regression-ANOVA.

\begin{tabular}{|c|c|c|c|c|c|c|}
\hline & Model & Sum of squares & df & Mean square & $\mathrm{F}$ & Sig. \\
\hline \multirow{3}{*}{1} & Regression & 29.087 & 1 & 29.087 & 322.771 & $0.000^{\mathrm{a}}$ \\
\hline & Residual & 10.273 & 114 & 0.090 & & \\
\hline & Total & 39.361 & 115 & & & \\
\hline
\end{tabular}

${ }^{\mathrm{a}}$ Predictors: (Constant), EAI; ${ }^{\mathrm{b}}$ Dependent variable: EB.

Table 9. Simple liner regression-coefficients.

\begin{tabular}{|c|c|c|c|c|c|c|}
\hline & \multirow{2}{*}{ Model } & \multicolumn{2}{|c|}{ Unstandardized coefficients } & Standardized coefficients & \multirow{2}{*}{$\mathrm{t}$} & \multirow{2}{*}{ Sig. } \\
\hline & & B & Std. error & Beta & & \\
\hline \multirow{2}{*}{1} & (Constant) & 0.554 & 0.189 & & 2.926 & 0.004 \\
\hline & EAI & 0.862 & 0.048 & 0.860 & 17.966 & 0.000 \\
\hline
\end{tabular}

${ }^{\mathrm{a}}$ Dependent variable: EB.

Table 10. Summary of hypothesis.

\begin{tabular}{|c|c|c|c|c|}
\hline Hypotheses & Statistics & Beta & p-value & Result \\
\hline $\begin{array}{l}\text { H1: There is a relationship between Perak State academics' e-filing } \\
\text { adoption intention and behaviour. }\end{array}$ & SLR & 0.862 & 0.000 & Accepted \\
\hline $\begin{array}{l}\text { H2: There is a relationship between perceived ease of use (PEU) and } \\
\text { Perak State academics' e-filing adoption intention. }\end{array}$ & MLR & 0.331 & 0.000 & Accepted \\
\hline $\begin{array}{l}\text { H3: There is a relationship between perceived usefulness (PU) and } \\
\text { Perak State academics' e-filing adoption intention. }\end{array}$ & MLR & 0.325 & 0.000 & Accepted \\
\hline $\begin{array}{l}\text { H4: There is a relationship between perceived security (PS) } \\
\text { and Perak State academics' e-filing adoption intention. }\end{array}$ & MLR & 0.105 & 0.007 & Accepted \\
\hline $\begin{array}{l}\text { H5: There is a relationship between perceived credibility (PC) } \\
\text { and Perak State academics' e-filing adoption intention. }\end{array}$ & MLR & 0.173 & 0.000 & Accepted \\
\hline $\begin{array}{l}\text { H6: There is a relationship between perceived service and information } \\
\text { quality (PSIQ) and Perak State academics' e-filing adoption intention. }\end{array}$ & MLR & 0.220 & 0.070 & Not accepted \\
\hline
\end{tabular}

\section{Conclusion}

This research served the purpose of investigating the factors affecting the Perak State academics' e-filing behaviour in using the e-filing system compared with the traditional manual tax filing system. Five constructs including perceived ease of use, perceived usefulness, perceived security, perceived credibility and perceived service and information quality were proposed to test the relationship with the e-filing adoption intention. According to the results generated by the Statistical Package for Social Science (SPSS), the researchers conclude that perceived ease of use, perceived usefulness, perceived security and perceived credibility are considered as the main determinants of the Perak State academics' behavioral intention towards the adoption of e-filing and perceived service and information quality is not influencing the e-filing adoption intention.

\section{References}

[1] Ahmad, M. (2002) Implementation of Electronic Government in Malaysia: The Status and Potential for Better Service to the Public. Public Sector ICT Management Review, No. 9.

[2] Sharma, S.K. and Yadav, R. (2011) An Empirical Study on Tax Payer's Attitude towards E-Return Filing in India. International Journal of Research in Computer Application and Management, 1, 20-24.

[3] Chong, K.F. and Lai, M.L. (2008) Electronic Tax Filing System: Taxpayers Perspectives. The 7th Wuhan International Conference on E-Business, E-Business Track, 338-344. 
[4] Hanefah, M.M. (2007) Tax Systems Taxpayer: Compliance and Specific Tax Issues. Universiti Utara Malaysia Press, Sintok.

[5] Ibrahim, I. and Pope, J. (2011) Compliance Costs of Electronic Tax Filing for Personal Taxpayers in Malaysia. International Conference on Management, 927-940.

[6] Petersen, J.F. and Washington, K.A. (1993) Why Electronic Filing Is Hot. Journal of Accountancy, 4, 68-70.

[7] Carter, L. and Belanger, F. (2001) Citizen Adoption of Electronic Government Initiatives. Proceedings of the 37th Hawaii International Conference on System Sciences, 3-10.

[8] Davis, F.D. (1989) Perceived Usefulness, Perceived Ease of Use, and User Acceptance of Information Technology. MIS Quarterly, 13, 319-340. http://dx.doi.org/10.2307/249008

[9] Legris, P., Ingham, J. and Collerette, P. (2003) Why Do People Use Information Technology? A Critical Review of the Technology Acceptance. Information and Management, 40, 191-204. http://dx.doi.org/10.1016/S0378-7206(01)00143-4

[10] Lin, F., Fofanah, S.S. and Liang, D. (2011) Assessing Citizen Adoption of E-Government Initiatives in Gambia: A Validation of the Technology Acceptance Model in Information System Success. Government Information Quarterly, 28, 271-279. http://dx.doi.org/10.1016/j.giq.2010.09.004

[11] Chang, I., Li, Y., Hung, W. and Hung, H. (2005) An Empirical Study on the Impact of Quality Antecedents on Academics’ Acceptance of Internet Tax Filing Systems. Government Information Quarterly, 22, 389-410. http://dx.doi.org/10.1016/j.giq.2005.05.002

[12] Hsu, C.L. and Lu, H.P. (2004) Why Do People Play Online Games? An Extended TAM with Social Influences and Flow Experience. Information and Management, 41, 853-868. http://dx.doi.org/10.1016/j.im.2003.08.014

[13] Lee, M.C. (2009) Factors Influencing the Adoption of Internet Banking: An Integration of TAM. Electronic Commerce Research and Applications, 8, 130-141. http://dx.doi.org/10.1016/j.elerap.2008.11.006

[14] Ajzen, I. (1991) The Theory of Planned Behaviour. Organizational Behaviour and Human Decision Processes, 50, 179-211. http://dx.doi.org/10.1016/0749-5978(91)90020-T

[15] Lu, C.T., Huang, S.Y. and Lo, P.Y. (2010) An Empirical Study of Online Tax Filing Acceptance Model: Integrating TAM and TPB. African Journal of Business Management, 4, 800-810.

[16] Pavlou, P.A. (2003) Consumer Acceptance of Electronic Commerce: Integrating Trust and Risk with the Technology Acceptance Model. International Journal of Electronic Commerce, 7, 101-134.

[17] Ambali, A.R. (2009) Digital Divide and Its Implication on Perak State E-Government: Policy Initiatives. In: Hakikur, R., Ed., Social and Political Implications of Data Mining: Knowledge Management in E-Government, Hershey, Information Science Reference (an Imprint of IGI Global). http://dx.doi.org/10.4018/978-1-60566-230-5.ch016

[18] Catholic Encyclopedia (2013) Intention. http://www.catholic.org/encyclopedia/

[19] Bhatti, T. (2007) Exploring Factors Influencing the Adoption of Mobile Commerce. Journal of Internet Banking and Commerce, 12, 1-13.

[20] Agarwal, R. and Prasad, J. (1999) Are Individual Differences Germane to the Acceptance of New Information Technologies? Decision Sciences, 30, 361-392. http://dx.doi.org/10.1111/j.1540-5915.1999.tb01614.x

[21] Azmi, A.C. and Bee, N.G. (2010) The Acceptance of the E-Filing System by Perak State Taxpayers: A Simplified Model. Electronic Journal of e-Government, 8, 13-22.

[22] Davis, F., Bagozzi, R. and Warshaw, P. (1989) User Acceptance of Computer Technology: A Comparison of Two Theoritical Models. Journal of Management Science, 35, 982-1003. http://dx.doi.org/10.1287/mnsc.35.8.982

[23] Hu, P.J., Chau, P.Y.K., Sheng, O.R.L. and Tam, K.Y. (1999) Examining the Technology Acceptance Model Using Physician Acceptance of Telemedicine Technology. Journal of Management Information Systems, 16, 91-112.

[24] Jackson, C.M., Chow, S. and Leitch, R.A. (1997) Toward an Understanding of the Behavioral Intention to Use an Information System. Decision Sciences, 28, 357-389. http://dx.doi.org/10.1111/j.1540-5915.1997.tb01315.x

[25] Venkatesh, V. and Davis, F.D. (2000) A Theoretical Extension of the Technology Acceptance Model: Four Longitudinal Field Studies. Management Science, 46, 186-204. http://dx.doi.org/10.1287/mnsc.46.2.186.11926

[26] Wang, Y.S. (2002) The Adoption of Electronic Tax Filing Systems: An Empirical Study. Government Information Quarterly, 20, 333-352. http://dx.doi.org/10.1016/j.giq.2003.08.005

[27] Iqbal, A. and Bagga, R.K. (2010) E-Governance: Issues in Implementation. http://www.academia.edu/233633/E-governance_Issues_In_Implementation

[28] Mathwick, C., Malhotra, N. and Rigdon, E. (2001) Experiential Value: Conceptualization, Measurement and Application in the Catalog and Internet Shopping Environment. Journal of Retailing, 77, 39-56.

http://dx.doi.org/10.1016/S0022-4359(00)00045-2 
[29] Gefen, D., Karahanna, E. and Straub, D.W. (2003) Trust and TAM in Online Shopping: An Integrated Model. MIS Quarterly, 27, 51-90.

[30] Hashim, J. (2008) Factors Influencing the Acceptance of Web-Based Training in Malaysia: Applying the Technology Acceptance Model. International Journal of Training and Development, 12, 253-264. http://dx.doi.org/10.1111/j.1468-2419.2008.00307.x

[31] Lallmahamood, M. (2007) An Examination of Individual's Perceived Security and Privacy of the Internet in Malaysia and the Influence of This on Their Intention to Use E-Commerce: Using an Extension of the Technology Acceptance Model. Journal of Internet Banking and Commerce, 12, 1-26.

[32] Jahangir, N. and Begum, N. (2008) The Role of Perceived Usefulness, Perceived Ease of Use, Security and Privacy, and Customer Attitude to Engender Customer Adaptation in the Context of Electronic Banking. African Journal of Business Management, 2, 32-40.

[33] Belanger, F., Hiller, J. and Smith, W. (2002) Trustworthiness in Electronic Commerce: The Role of Privacy, Security, and Site Attributes. Journal of Strategic Information Systems, 11, 245-270. http://dx.doi.org/10.1016/S0963-8687(02)00018-5

[34] Valacich, J. and Schneider, C. (2012) Information Systems Today: Managing in the Digital World. 5th Edition, Pearson Prentice Hall, Upper Saddle River.

[35] Chellapa, R.K. and Pavlou, P.A. (2002) Perceived Information Security, Financial Liability and Consumer Trust in Electronic Commerce Transactions. Logistics Information System, 15, 358-368. http://dx.doi.org/10.1108/09576050210447046

[36] Speier, C., Valacich, J.S. and Vessey, I. (2003) The Effects of Interruptions, Task Complexity and Information Presentation on Computer-Supported Decision Making Performance. Decision Sciences, 34, 771-797. http://dx.doi.org/10.1111/j.1540-5414.2003.02292.x

[37] Alfawaz, S., May, L. and Mohanak, K. (2008) E-Government Security in Developing Countries: A Managerial Conceptual Framework.

[38] West, S.G., Finch, J.F. and Curran, P.J. (1995) Structural Equation Models with Non Normal Variables: Problems and remedies. In: Hoyle, R.H., Ed., Structural Equation Modeling: Concepts, Issues, and Applications, Sage, Thousand Oaks, 56-75.

[39] Udo, G.J. (2001) Privacy and Security Concerns as Major Barriers for E-Commerce: A Survey Study. Information Management \& Computer Security, 9, 165-174.

[40] Lai, M.L., Sheikh Obid, S.N. and Meera, A.K. (2004) Towards an Electronic Filing System: A Malaysian Survey. eJournal of Tax Research, 2, 1-15.

[41] Ilias, A., Razak, M.Z.A. and Yasoa, M.R. (2009) Taxpayers’ Attitude in Using E-Filing System: Is There Any Significant Difference among Demographic Factors? Journal of Internet Banking and Commerce, 14, 1-13.

[42] Ilhaamie, A.G.A. (2010) Service Quality in Perak State Public Service: Some Findings. International Journal of Trade, Economics and Finance, 1.

[43] Ramayah, T., Ramoo, V. and Ibrahim, A. (2008) Profiling Online and Manual Tax Filers: Results from an Explaratory Study in Penang, Malaysia. Labuan e-Journal of Muamalat and Society, 2, 1-8.

[44] Abdullah, F. (2006) The Development of HEdPERF: A New Measuring Instrument of Service Quality for the Higher Education Sector. International Journal of Consumer Studies, 30, 569-581. http://dx.doi.org/10.1111/j.1470-6431.2005.00480.x

[45] Aliah, H.M.S. and Tarmizi, A.A.R. (1998) Jurang Harapan-Tanggapan Pengguna: Suatu Pengukuran Kualiti Perkhidmatan Pembayaran Cukai Pendapatan di Malaysia. Journal Pengurusan, 17, 69-92.

[46] Delone, W.H. and Mclean, E.R. (2003) The DeLone and McLean Model of Information Systems Success: A Ten-Year Update. Journal of Management Information Systems, 19, 9-30.

[47] Aziz, A.S. and Idris, M.K. (2012) The Determinants of Tax E-Filing among Tax Preparers in Malaysia. World Journal of Social Sciences, 2, 182-188. 


\section{Appendix. Filing Adoption Behaviour among Taxpayers in Perak State}

Dear respondent:

\section{Survey Questionnaire}

1) We are doing research on the E-Filing of income tax returns.

2) There are THREE (3) sections in this questionnaire. Please answer ALL questions in ALL sections.

3) Completion of this form will take you approximately 10 to 15 minutes.

4) The contents of this questionnaire will be kept strictly confidential.

Thank you for your participation.

\section{Section A : Demographic Profile}

Please place a tick " $\sqrt{ }$ " for each of the following:

1. Your Tax Filing method for the year 2011:

Manual

Through online

2. Gender:

Male

Female

3. Age:

$21-30$

$31-40$

$41-50$

51 or above

4. Marital status:

Single

Married

5. Education:

Bachelor

Master

PHD

Specialist

6. Monthly Income Level:

RM 2500 - RM 3500

RM 3501 - RM 4500

RM 4501 - RM 5500

RM 5501 or above

7. Computer and network facilities at home:

Have no computer

Have computer(s) but cannot connect to Internet

Dial up connection

Broadband (ADSL, Cable Modem)

8. Computer and network facilities at work:

Have no computer

Have computer(s) but cannot connect to Internet

Dial up connection

LAN

Broadband (ADSL, Cable Modem) 
9. Average hours of computer use in a week:

1 or less

$2-4$

$5-7$

8 or above

Section B: Factors Affecting E-Filing Adoption Intention and Behaviour

Please circle your answer to each statement using 5 Likert scale [(1) = Strongly disagree; (2) = Disagree; (3) = Neutral; (4) = Agree and (5) = Strongly agree].

\section{Perceived Ease of Use}

\begin{tabular}{|c|c|c|c|c|c|c|}
\hline No. & Questions & Strongly disagree & Disagree & Neutral & Agree & Strongly agree \\
\hline 1 & $\begin{array}{l}\text { Learning to use tax E-filing and payment system } \\
\text { would be easy for me. }\end{array}$ & 1 & 2 & 3 & 4 & 5 \\
\hline 2 & $\begin{array}{l}\text { I would find it is easy to prepare income tax } \\
\text { filing using E-filing and payment system. }\end{array}$ & 1 & 2 & 3 & 4 & 5 \\
\hline 3 & $\begin{array}{l}\text { It would be easy for me to become skillful at } \\
\text { using tax E-filing and payment system. }\end{array}$ & 1 & 2 & 3 & 4 & 5 \\
\hline 4 & $\begin{array}{l}\text { Instruction for using tax E-filing and payment } \\
\text { system will be easy to follow. }\end{array}$ & 1 & 2 & 3 & 4 & 5 \\
\hline 5 & $\begin{array}{l}\text { I would find tax E-filing and payment system } \\
\text { easy to use. }\end{array}$ & 1 & 2 & 3 & 4 & 5 \\
\hline
\end{tabular}

\section{Perceived Usefulness}

\begin{tabular}{|c|c|c|c|c|c|c|}
\hline No. & Questions & Strongly disagree & Disagree & Neutral & Agree & Strongly agree \\
\hline 1 & $\begin{array}{l}\text { Using tax E-filing and payment system would } \\
\text { improve my performance in tax filling. }\end{array}$ & 1 & 2 & 3 & 4 & 5 \\
\hline 2 & $\begin{array}{l}\text { Using tax E-filing and payment system would } \\
\text { speed up the tax filing process. }\end{array}$ & 1 & 2 & 3 & 4 & 5 \\
\hline 3 & $\begin{array}{l}\text { Using tax E-filing and payment system would } \\
\text { enhance my effectiveness in tax filling. }\end{array}$ & 1 & 2 & 3 & 4 & 5 \\
\hline 4 & $\begin{array}{l}\text { Using tax E-filing and payment system enables me } \\
\text { to get refund from tax agency quickly. }\end{array}$ & 1 & 2 & 3 & 4 & 5 \\
\hline 5 & $\begin{array}{l}\text { I would find tax E-filing and payment system } \\
\text { useful in preparing income tax filing. }\end{array}$ & 1 & 2 & 3 & 4 & 5 \\
\hline
\end{tabular}

\section{Perceived Security}

\begin{tabular}{|c|c|c|c|c|c|c|}
\hline No. & Questions & Strongly disagree & Disagree & Neutral & Agree & Strongly agree \\
\hline 1 & $\begin{array}{l}\text { It is important that I feel safe and secure when } \\
\text { I do tax E-filing. }\end{array}$ & 1 & 2 & 3 & 4 & 5 \\
\hline 2 & $\begin{array}{l}\text { It is important that I feel secure if I know that tax } \\
\text { officer received and accepted my E-filing return. }\end{array}$ & 1 & 2 & 3 & 4 & 5 \\
\hline 3 & $\begin{array}{l}\text { It is safe and secure to give out bank account } \\
\text { numbers over a computer. }\end{array}$ & 1 & 2 & 3 & 4 & 5 \\
\hline 4 & $\begin{array}{l}\text { It is secure if document is sent electronically } \\
\text { than sent by courier or hand delivery. }\end{array}$ & 1 & 2 & 3 & 4 & 5 \\
\hline 5 & $\begin{array}{l}\text { I wish things to look secure for me in the } \\
\text { future in the tax E-filing system. }\end{array}$ & 1 & 2 & 3 & 4 & 5 \\
\hline
\end{tabular}

\section{Perceived Credibility}

\begin{tabular}{|c|c|c|c|c|c|c|}
\hline No. & Questions & Strongly disagree & Disagree & Neutral & Agree & Strongly agree \\
\hline 1 & I trust on the technology used in tax E-filing. & 1 & 2 & 3 & 4 & 5 \\
\hline 2 & $\begin{array}{l}\text { I trust in the ability of tax authorities to protect } \\
\text { submitted information. }\end{array}$ & 1 & 2 & 3 & 4 & 5 \\
\hline 3 & $\begin{array}{l}\text { I believe that submitted information is not } \\
\text { subject to alteration/loss. }\end{array}$ & 1 & 2 & 3 & 4 & 5 \\
\hline 4 & $\begin{array}{l}\text { I believe that tax E-filing system is well } \\
\text { tested and documented. }\end{array}$ & 1 & 2 & 3 & 4 & 5 \\
\hline
\end{tabular}




\begin{tabular}{|c|c|c|c|c|c|c|}
\hline No. & Questions & Strongly disagree & Disagree & Neutral & Agree & Strongly agree \\
\hline 1 & $\begin{array}{l}\text { I prefer to use E-filing service rather than } \\
\text { manual return method. }\end{array}$ & 1 & 2 & 3 & 4 & 5 \\
\hline 2 & $\begin{array}{l}\text { E-filing service will benefit me and } \\
\text { provide a good quality service. }\end{array}$ & 1 & 2 & 3 & 4 & 5 \\
\hline 3 & $\begin{array}{l}\text { I prefer to use E-filing service if the } \\
\text { site is well organized. }\end{array}$ & 1 & 2 & 3 & 4 & 5 \\
\hline 4 & $\begin{array}{l}\text { I prefer to use E-filing service if the } \\
\text { information in the site is enough. }\end{array}$ & 1 & 2 & 3 & 4 & 5 \\
\hline 5 & $\begin{array}{l}\text { I prefer to use E-filing service if the } \\
\text { site does not take too long to load the page. }\end{array}$ & 1 & 2 & 3 & 4 & 5 \\
\hline
\end{tabular}

\section{Section C: E-Filing Adoption Intention and Behavior}

Please circle your answer to each statement using 5 Likert scale [(1) = Strongly disagree; (2) = Disagree; (3) = Neutral; (4) = Agree and (5) = Strongly agree].

\section{E-Filing Adoption Intention}

\begin{tabular}{|c|c|c|c|c|c|c|}
\hline No. & Questions & Strongly disagree & Disagree & Neutral & Agree & Strongly agree \\
\hline 1 & $\begin{array}{l}\text { I intend to use E-filing and payment system for } \\
\text { the next tax filing season. }\end{array}$ & 1 & 2 & 3 & 4 & 5 \\
\hline 2 & $\begin{array}{l}\text { I intend to use E-filing and payment system on } \\
\text { a regular basis in the future. }\end{array}$ & 1 & 2 & 3 & 4 & 5 \\
\hline 3 & I expect to use E-filing and payment system. & 1 & 2 & 3 & 4 & 5 \\
\hline 4 & $\begin{array}{l}\text { In choosing method for filing my tax return, } \\
\text { E-filing and payment system is my priority. }\end{array}$ & 1 & 2 & 3 & 4 & 5 \\
\hline 5 & $\begin{array}{l}\text { I would like to recommend tax E-filing and } \\
\text { payment system to my relatives and friends. }\end{array}$ & 1 & 2 & 3 & 4 & 5 \\
\hline
\end{tabular}

\section{E-Filing Behaviour}

\begin{tabular}{|c|c|c|c|c|c|c|}
\hline No. & Questions & Strongly disagree & Disagree & Neutral & Agree & Strongly agree \\
\hline 1 & I use E-filing because it is easy to use. & 1 & 2 & 3 & 4 & 5 \\
\hline 2 & $\begin{array}{l}\text { I use E-filing since it improves my tax return } \\
\text { filing performance. }\end{array}$ & 1 & 2 & 3 & 4 & 5 \\
\hline 3 & I use E-filing because of its perceived credibility. & 1 & 2 & 3 & 4 & 5 \\
\hline 4 & I use E-filing because I feel secured. & 1 & 2 & 3 & 4 & 5 \\
\hline 5 & $\begin{array}{l}\text { I adopt E-filing because it provides a good } \\
\text { service and information quality. }\end{array}$ & 1 & 2 & 3 & 4 & 5 \\
\hline 6 & $\begin{array}{l}\text { I use E-filing system each time I want to file } \\
\text { my tax return. }\end{array}$ & 1 & 2 & 3 & 4 & 5 \\
\hline
\end{tabular}

